Note

\section{Intact Cell Transformation of Saccharomyces cerevisiae by Polyethylene Glycol}

\author{
Minoru Yamakawa, ${ }^{*}$ Fumio Hishinuma \\ and Norio GuNGE** \\ Mitsubishi-Kasei Institute of Life Sciences, \\ Minamiooya, Machida-shi, \\ Tokyo 194, Japan
}

Received September 5, 1984

A new yeast transformation method using intact cells instead of protoplasts has recently been developed. ${ }^{1,2)}$ This transformation method is based on the treatment of intact cells with alkali cations such as lithium acetate or thiol compounds. It has several advantages compared with the current protoplast method $^{3)}$; for example, since lytic enzyme digestion of yeast cell walls can be avoided, regeneration agar is not necessary and transformant colonies appear significantly faster ( $2 \sim 4$ days $)$.

In the course of efforts to develop new yeast host vector systems we have found that intact cells treated with only polyethylene glycol (PEG) can be transformed. In this paper we present evidence for this observation.

The transformation procedure is principally based on the method reported by Ito et al. ${ }^{1,2)}$ The Saccharomyces cerevisiae strains, AH22 (a leu2-3 leu2-12 his4-519 can1), YNN27 ( $\alpha$ trp1 ura3 gal2) and D13-1A (a his3-532 trp1 gal2), were precultured overnight in $1 \mathrm{ml}$ of YEPD $(1.0 \%$ yeast extract, $2.0 \%$ polypepton, $2.0 \%$ glucose, $\mathrm{pH} 5.3$ ). Twenty $\mathrm{ml}$ of YEPD containing $0.4 \mathrm{ml}$ of a precultured cell suspension was incubated at $30^{\circ} \mathrm{C}$ with shaking until cell growth reached the late log phase. Cells were then harvested by centrifugation at $1000 \times g$ for $5 \mathrm{~min}$ and washed once with TE buffer $(10 \mathrm{~mm}$ Tris- $\mathrm{HCl}$ buffer, $\mathrm{pH}$ 7.5 , containing $1 \mathrm{~mm}$ EDTA). Then the cells were suspended at a concentration of $2 \times 10^{8}$ cells $/ \mathrm{ml}$ in the same buffer. Five hundred $\mu \mathrm{l}$ of TE buffer containing $0.2 \mathrm{M}$ lithium acetate (lithium acetate method of Ito et al. ${ }^{1.2)}$ ) or the same volume of TE buffer alone (polyethylene glycol method) was then added to $500 \mu$ l of the cell suspension. After $1 \mathrm{hr}$ incubation at $30^{\circ} \mathrm{C}$ with shaking, a $100 \mu \mathrm{l}$ portion of each cell suspension was added to the plasmid solution containing $10 \mu \mathrm{g}$ DNA. As DNA vectors the following plasmids were used: pDB248 (leu2 for AH22, $\mathrm{Ap}^{\mathrm{r}}, \mathrm{Tc}^{\mathrm{r}}$ for HB101), YRp7 (trp1 for YNN27 and D13-1A, $\mathrm{Ap}^{\mathrm{r}}, \mathrm{Tc}^{\mathrm{r}}$ for HB101) and G1053 (ura3 for YNN 27. Ap ${ }^{\mathrm{r}}$,
$\mathrm{Tc}^{\mathrm{r}}$ for $\left.\mathrm{HB} 101\right)$. After incubation for $30 \mathrm{~min}$ at $30^{\circ} \mathrm{C}$, either $100 \mu \mathrm{l}$ of $70 \%$ PEG 4000 in TE buffer or the same volume of TE buffer containing no PEG (as a control) was added and mixed in carefully. These samples were further incubated at $30^{\circ} \mathrm{C}$ for $1 \mathrm{hr}$ and then kept at $42^{\circ} \mathrm{C}$ in a water bath for $5 \mathrm{~min}$. Each cell suspension was cooled to room temerature and washed twice with $1 \mathrm{ml}$ of water. A $0.2 \mathrm{ml}$ portion of this cell suspension was spread on a selection agar plate containing $0.7 \%$ yeast nitrogen base, $2.0 \%$ glucose and $50 \mu \mathrm{g} / \mathrm{ml}$ of an amino acid or uracil (Lhistidine for $\mathrm{Leu}^{+}$and $\mathrm{Trp}{ }^{+}$transformants of AH22 and D13-1A, respectively, L-tryptophan for $\mathrm{Ura}^{+}$transformants of YNN27, and uracil for $\operatorname{Trp}^{+}$transformants of YNN27). The culture plates were then incubated at $30^{\circ} \mathrm{C}$ for $3 \sim 5$ days and the colonies produced were counted as transformants. For the detection of the plasmid in the cells, each transformed $S$. cerevisiae strain was grown in $4 \mathrm{ml}$ of the selection medium described above, and total DNA was extracted from the cells. ${ }^{4)}$ Escherichia coli strain HB101 cells were then transformed with these DNA

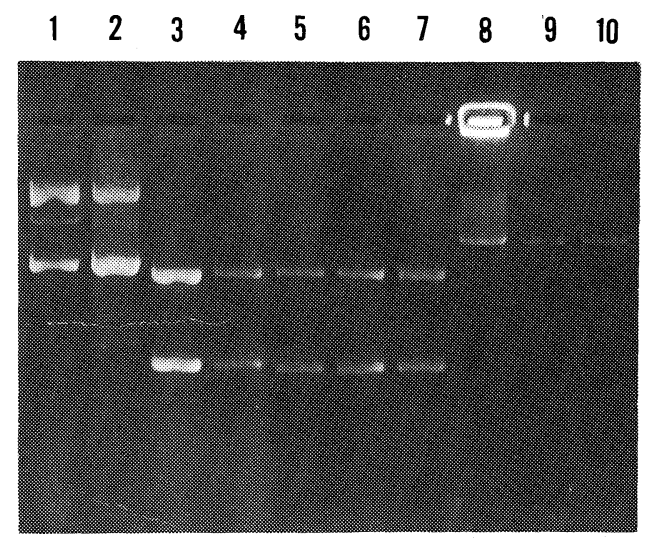

FIG. 1. Analysis of Plasmids in Transformants Obtained by the Polyethylene Glycol Method.

E. coli HB101 was transformed with DNA extracted from yeast transformants. Amplified plasmids in E. coli were analyzed by $0.7 \%$ agarose gel electrophoresis. The experimental conditions were given in detail in the text. In lanes $1 \sim 7$, open circular (upper band) and closed circular (lower band) forms of plasmids can be seen. Lanes 1, 3 and 8 contain marker plasmids of PDB248, YRp7 and G1053, respectively. Lane 2 contains plasmids extracted from $E$. coli strain HB101, which had been transformed with DNA samples from yeast transformants of AH22 + PDB248. The original yeast transformants from which DNA was isolated for lanes $4 \sim 7,9$ and 10 were YNN27 $\left(\rho^{\circ}\right)+$ YRp7, YNN27 $\left(\rho^{+}\right)+$YRp7, D13-1A $\left(\rho^{\circ}\right)+$ YRp7, D13-1A $\quad\left(\rho^{+}\right)+$YRp7, $\quad$ YNN27 $\quad\left(\rho^{\circ}\right)+$ G1053 and YNN27 $\left(\rho^{+}\right)+$G1053, respectively.

* Present address: Yale University School of Medicine, Department of Human Genetics, 333 Cedar Street, New Haven, CT 06510 U.S.A.

** To whom reprint requests should be addressed. 
Table I. Transformation of $S$. cerevisiae Strains by Different Plasmid Vectors with the Lithium Acetate- and Polyethylene Glycol Methods

A yeast strain containing mitochondrial DNA is designated as $\rho^{+}$and a strain containing no mitochondrial DNA as $\rho^{\circ}$. + shows the treatment of yeast cells with lithium acetate $\left(\mathrm{CH}_{3} \mathrm{COOLi}\right)$ or PEG. On the other hand, cells treated with buffer instead of $\mathrm{CH}_{3} \mathrm{COOLi}$ or PEG are indicated as -

\begin{tabular}{|c|c|c|c|c|c|}
\hline \multirow{2}{*}{ Strain } & \multirow{2}{*}{$\mathrm{CH}_{3} \mathrm{COOLi}$} & \multirow{2}{*}{ Plasmid } & \multirow{2}{*}{ PEG } & \multicolumn{2}{|c|}{$\begin{array}{l}\text { No. of transformants } \\
\text { (per } 10 \mu \mathrm{g} \mathrm{DNA})\end{array}$} \\
\hline & & & & $\rho^{+}$ & $\rho^{\circ}$ \\
\hline \multirow{4}{*}{$\mathrm{AH} 22$} & + & \multirow{4}{*}{ PDB248 } & - & & 0 \\
\hline & + & & + & & 1420 \\
\hline & - & & - & & 1 \\
\hline & - & & + & & 313 \\
\hline \multirow{4}{*}{ YNN27 } & + & \multirow{4}{*}{ YRp7 } & - & 2 & 1 \\
\hline & + & & + & 1341 & 506 \\
\hline & - & & - & 0 & 1 \\
\hline & - & & + & 309 & 15 \\
\hline \multirow{4}{*}{ YNN27 } & + & \multirow{4}{*}{ GI053 } & - & 0 & 0 \\
\hline & + & & + & 139 & 14 \\
\hline & - & & - & 0 & 0 \\
\hline & - & & + & 235 & 91 \\
\hline \multirow{4}{*}{ D13-1A } & + & \multirow{4}{*}{ YRp7 } & - & 1 & 3 \\
\hline & + & & + & 967 & 93 \\
\hline & - & & - & 1 & 2 \\
\hline & - & & + & 682 & 12 \\
\hline
\end{tabular}

samples. ${ }^{5)}$ Tetracycline and ampicillin resistant colonies were selected as transformants. After amplification in $E$. coli, plasmids were extracted from $5 \mathrm{ml}$ of culture fluid (6) and analyzed by $0.7 \%$ agarose gel electrophoresis. ${ }^{7)}$

The transformation efficiencies were analyzed as to the following points; a) presence or absence of mitochondrial DNA $\left(\rho^{+}\right.$or $\rho^{\circ}$ cells), b) difference of strains (AH22, YNN27 and D13-1A), c) difference of plasmids (PDB248, YNN27 and G1053), and d) difference of transformation methods (lithium acetate and PEG methods).

Table I and Fig. 1 show that for all $S$. cerevisiae strains used in this experiment, transformation was achieved by only PEG treatment of intact cells, although the efficiency was less than that with the lithium acetate method, with the exception of the transformation of YNN27 with G1053. The transformation efficiency varied depending upon the host strains employed, but it should be stressed that within the same strain, $\rho^{+}$cells were generally more efficient than $\rho^{\circ}$ cells.

From the results described above, we propose that treatment of intact cells with PEG is a minimal requirement for successful transformation and the uptake of plasmids is accelerated by alkali cations or thiol compounds.

Since the PEG method is very quick and simple, it has the potential of becoming a convenient and useful pro- cedure if the transformation efficiency can be raised to a level comparable to that of the current protoplast method. In the course of the preparation of this manuscript, a report was published on transformation by PEG treatment, the efficiency of which is comparable to that of the protoplast method. ${ }^{8)}$ In this work the general utility of the PEG method has been shown in a wide variety of organisms including yeast, $E$. coli and cultured human cell lines. Further optimization of the PEG transformation method for yeast cells may be required and the mechanism of the PEG effect in yeast transformation remains to be elucidated.

\section{REFERENCES}

1) H. Ito, Y. Fukuda, K. Murata and A. Kimura, J. Bacteriol., 153, 163 (1983).

2) H. Ito, K. Murata and A. Kimura, Agric. Biol. Chem., 48, 341 (1984).

3) A. Hinnen, J. B. Hicks and G. R. Fink, Proc. Natl. Acad. Sci. U.S.A., 75, 1929 (1978).

4) R. Davis, M. Thomas, J. Cameron, T. St. John, S. Scherer and R. A. Padgett, "Methods in Enzymology," Vol. 65, ed. by L. Grossman and K. Moldave, Academic Press, New York, 1979, pp. $404 \sim 411$. 
5) T. Maniatis, E. F. Fritsch and J. Sambrook, "Molecular Cloning: A Laboratory Manual," Cold Spring Harbor Laboratory, Cold Spring Harbor, New York, 1982, pp. $250 \sim 251$.

6) H. C. Birnboim and J. Doly, Nucleic Acids Res., 7,
1513 (1979).

7) P. S. Sharp, B. Sugden and J. Sambrook, Biochemistry, 12, 3055 (1973).

8) R. J. Klebe, J. V. Harriss, Z. D. Sharp and M. G. Douglas, Gene, 25, 333 (1983). 